\title{
Radiocarbon
}

1991

\section{LATE QUATERNARY PTEROPOD PRESERVATION IN EASTERN NORTH ATLANTIC SEDIMENTS IN RELATION TO CHANGING CLIMATE}

\author{
G. M. GANSSEN, S. R. TROELSTRA \\ Geomarine Center, Institute of Earth Sciences, Free University, P.O. Box 7161 \\ 1007 MC Amsterdam, The Netherlands
}

\section{KLAAS VAN DER BORG and A. M. F. DE JONG}

Robert J. van der Graaff Laboratorium, State University Utrecht, Box 80.000, 3508 TA Utrecht The Netherlands

\begin{abstract}
AMS ${ }^{14} \mathrm{C}$ measurements on pteropod shells from eastern North Atlantic deep-sea cores reveal distinct periods of aragonite preservation during the last 16,000 years. Most preservation spikes coincide with documented periods of climatic change on a scale of $2 \times 10^{1}$ to $2 \times 10^{3}$ years.
\end{abstract}

\section{INTRODUCTION}

Pteropods are fully marine pelagic gastropods that build a shell composed of aragonite. After death of the organism, the shell starts its descent to the sea floor. Because most seawater below the thermocline is undersaturated with aragonite, dissolution of the pteropods starts at an early stage and is enhanced on the sea floor. The final inclusion of well-preserved shells in deep-sea sediments is, thus, an exception (Berner 1977). On the North Atlantic sea floor, pteropod shells are generally absent from depths exceeding $2800 \mathrm{~m}$ (Berner 1977; Berger 1978); high productivity may even raise the position of the aragonite compensation depth (ACD) to shallower depths, as is the case along the northeastern continental margin at $45^{\circ} \mathrm{N}$ (Ganssen \& Lutze 1982).

During the North Atlantic Actuomicropaleontology Paleoceanography North Atlantic Project (APNAP) 1986/88 cruises with the $R / V$ Tyro, up to 13 -cm-thick pteropod oozes were encountered on box core surface sediments from $45^{\circ}-48^{\circ} \mathrm{N}$ at depths between 2700 and $3100 \mathrm{~m}$. In addition, several cores contained lenses of fragmented pteropod shells. Species composition was almost monospecific with Diacria trispinosa abundantly present. The shells showed a $\mathrm{Fe} / \mathrm{Mn}$ staining scale from almost white to dark brown. Similar findings were made by Price, Killingley and Berger (1985) on the Rio Grande Rise. We encountered no true "pteropod pavements" south of $45^{\circ} \mathrm{N}$, but observed aragonite preservation and $\mathrm{Fe} / \mathrm{Mn}$ staining in the species Cuvierina columnella.

Pilot accelerator mass spectrometry (AMS) ${ }^{14} \mathrm{C}$ measurements on various staining groups from Core T86/5B, yielded ages between 500 and 3100 B.P. (no correction for reservoir age), indicating that preservation of pteropod shells at this site had been going on for a considerable period of time (Troelstra et al. 1987). Apparently, either the position of the ACD in this area was deeper than $2800 \mathrm{~m}$ or a particular hydrographic regime, or both, favored aragonite preservation. We discuss this subject in detail elsewhere (Melkert et al., ms). 


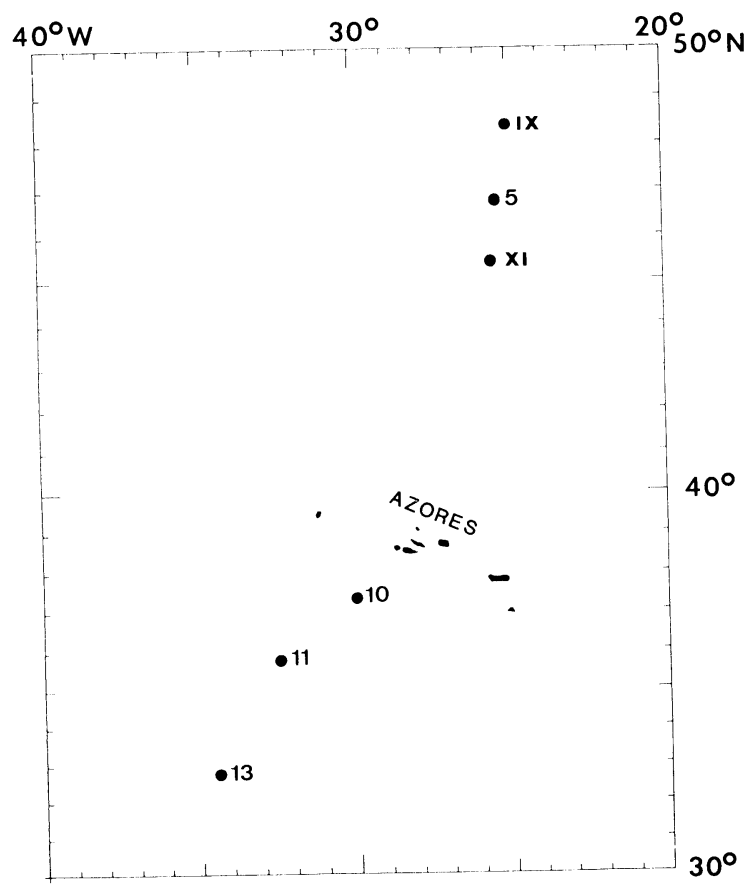

Fig. 1. Location of the box cores from the northeastern Atlantic Ocean discussed in this paper. Arabic numbers refer to box cores taken during APNAP cruise 1986; Roman numbers refer to box cores from APNAP cruise 1988.

We present the results of AMS ${ }^{14} \mathrm{C}$ measurements performed on individual pteropod shells from eastern North Atlantic box cores along a traverse, $32^{\circ}-48^{\circ} \mathrm{N}$. Speculations are made on the relation of aragonite preservation to climatic development in this area during the late Quaternary.

\section{MATERIAL AND METHODS}

The material described in this paper derives from six box cores taken in the northeastern Atlantic during the 1986 and 1988 APNAP cruises with the R/V Tyro (Fig. 1). Core location, water depth and recovery are indicated in Table 1. Preparation of the aragonitic/calcitic shells followed standard procedures (Hut, Ostlund \& van der Borg 1986). In a few cases, the sediments directly underlying the pteropod ooze were dated on bulk planktonic foraminiferal material.

TABLE 1. Station location, water depth and core recovery of northeastern Atlantic material discussed in the text

\begin{tabular}{llllc}
\hline Station & Latitude & Longitude & Depth $(\mathrm{m})$ & Recovery $(\mathrm{cm})$ \\
\hline T88/9B & $48^{\circ} 23^{\prime} \mathrm{N}$ & $25^{\circ} 05^{\prime} \mathrm{W}$ & 3074 & 28 \\
$\mathrm{~T} 86 / 5 \mathrm{~B}$ & $46^{\circ} 53^{\prime} \mathrm{N}$ & $25^{\circ} 21^{\prime} \mathrm{W}$ & 3121 & 38 \\
$\mathrm{~T} 88 / 11 \mathrm{~B}$ & $45^{\circ} 24^{\prime} \mathrm{N}$ & $25^{\circ} 26^{\prime} \mathrm{W}$ & 2741 & 26 \\
$\mathrm{~T} 86 / 10 \mathrm{~S}$ & $37^{\circ} 07^{\prime} \mathrm{N}$ & $30^{\circ} 02^{\prime} \mathrm{W}$ & 2610 & 36.5 \\
$\mathrm{~T} 86 / 11 \mathrm{~S}$ & $35^{\circ} 44^{\prime} \mathrm{N}$ & $32^{\circ} 33^{\prime} \mathrm{W}$ & 2220 & 14 \\
T86/13B & $32^{\circ} 46^{\prime} \mathrm{N}$ & $34^{\circ} 42^{\prime} \mathrm{W}$ & 2992 & 17 \\
& & $32^{\circ} 22^{\prime} \mathrm{W}$ & 100 (water col- & \\
DANA41953* & $41^{\circ} 55^{\prime} \mathrm{N}$ & & umn) & \\
\end{tabular}

* The DANA sample refers to pteropod net samples, collected $22 / 6 / 1931$ at a depth of $100 \mathrm{~m}$ in the water column. 
TABLE 2. AMS ${ }^{14} \mathrm{C}$ Measurements on material discussed in this paper

\begin{tabular}{|c|c|c|c|c|c|}
\hline Station no. & UtC no. & $\begin{array}{l}\text { Position in } \\
\text { core }(\mathrm{cm})\end{array}$ & $\begin{array}{l}\text { Type of } \\
\text { organism }\end{array}$ & $\begin{array}{l}\Delta^{13} \mathrm{C}^{\dagger} \\
(\% 0)\end{array}$ & Age $\mathrm{BP}^{\ddagger}$ \\
\hline $\begin{array}{l}\text { DANA41953* } \\
\text { DANA41953 } \\
\text { T88/9B } \\
\text { T88/9B } \\
\text { T88/9B } \\
\text { T88/9B } \\
\text { T88/9B } \\
\text { T88/9B } \\
\text { T88/9B } \\
\text { T88/9B } \\
\text { T88/9B } \\
\text { T88/9B }\end{array}$ & $\begin{array}{l}1033 \\
1034 \\
1031 \\
1032 \\
1023 \\
1027 \\
1024 \\
1028 \\
1025 \\
1029 \\
1026 \\
1030\end{array}$ & $\begin{array}{l}100 \mathrm{~m} \text { (water column) } \\
100 \mathrm{~m} \text { (water column) } \\
17-18 \\
18-19.5 \\
\text { **1. } 0-2 \\
\text { 1. } 12-14 \\
\text { 2. } 0-2 \\
\text { 2. } 12-14 \\
\text { 3. } 0-2 \\
\text { 3. } 12-14 \\
\text { 4. } 0-2 \\
\text { 4. } 12-14\end{array}$ & $\begin{array}{l}\text { Diacria } \\
\text { Diacria } \\
\text { Pter. fragments } \\
\text { Pter. fragments } \\
\text { Diacria } \\
\text { Pter. fragments } \\
\text { Diacria } \\
\text { Pter. fragments } \\
\text { Diacria } \\
\text { Pter. fragments } \\
\text { Diacria } \\
\text { Pter. fragments }\end{array}$ & $\begin{array}{l}2.50 \\
2.10 \\
2.03 \\
1.90 \\
1.10 \\
2.03 \\
2.40 \\
2.21 \\
2.30 \\
1.74 \\
2.40 \\
1.67\end{array}$ & $\begin{aligned} 480 & \pm 50 \\
370 & \pm 70 \\
3690 & \pm 80 \\
7230 & \pm 100 \\
550 & \pm 60 \\
3690 & \pm 80 \\
600 & \pm 100 \\
3970 & \pm 80 \\
1210 & \pm 60 \\
4970 & \pm 70 \\
1870 & \pm 110 \\
8020 & \pm 110\end{aligned}$ \\
\hline $\begin{array}{l}\mathrm{T} 86 / 5 \mathrm{~B} \\
\mathrm{~T} 86 / 5 \mathrm{~B} \\
\mathrm{~T} 86 / 5 \mathrm{~B} \\
\mathrm{~T} 86 / 5 \mathrm{~B} \\
\mathrm{~T} 86 / 5 \mathrm{~B} \\
\mathrm{~T} 86 / 5 \mathrm{~B} \\
\mathrm{~T} 86 / 5 \mathrm{~B} \\
\mathrm{~T} 86 / 5 \mathrm{~B} \\
\mathrm{~T} 86 / 5 \mathrm{~B} \\
\mathrm{~T} 86 / 5 \mathrm{~B} \\
\mathrm{~T} 86 / 5 \mathrm{~B} \\
\mathrm{~T} 86 / 5 \mathrm{~B} \\
\mathrm{~T} 86 / 5 \mathrm{~B} \\
\mathrm{~T} 86 / 5 \mathrm{~B} \\
\mathrm{~T} 86 / 5 \mathrm{~B} \\
\mathrm{~T} 86 / 5 \mathrm{~B} \\
\mathrm{~T} 86 / 5 \mathrm{~B} \\
\mathrm{~T} 86 / 5 \mathrm{~B} \\
\mathrm{~T} 86 / 5 \mathrm{~B} \\
\mathrm{~T} 86 / 5 \mathrm{~B}\end{array}$ & $\begin{array}{l}423 \\
648 \\
422 \\
421 \\
649 \\
418 \\
650 \\
417 \\
416 \\
415 \\
414 \\
699 \\
700 \\
441 \\
437 \\
425 \\
440 \\
439 \\
438 \\
424\end{array}$ & $\begin{array}{l}\text { 1. } 0-1 \\
\text { 1. } 0-1 \\
\text { 1. } 0-1 \\
\text { 2. } 0-1 \\
\text { 2. } 0-1 \\
\text { 2. } 0-1 \\
\text { 2. } 0-1 \\
\text { 3. } 0-1 \\
\text { 3. } 0-1 \\
\text { 4. } 0-1 \\
\text { 4. } 0-1 \\
2-3 \\
3-4 \\
\text { 1. } 1-2 \\
\text { 1. } 1-2 \\
\text { 1. } 1-2 \\
\text { 3. } 1-2 \\
\text { 3. } 1-2 \\
\text { 3. } 1-2 \\
\text { 4. } 1-2\end{array}$ & $\begin{array}{l}\text { Diacria } \\
\text { Diacria } \\
\text { Diacria } \\
\text { Diacria } \\
\text { Diacria } \\
\text { Diacria } \\
\text { Diacria } \\
\text { Diacria } \\
\text { Diacria } \\
\text { Diacria } \\
\text { Diacria } \\
\text { Forams } \\
\text { Forams } \\
\text { Diacria } \\
\text { Diacria } \\
\text { Diacria } \\
\text { Diacria } \\
\text { Diacria } \\
\text { Diacria } \\
\text { Diacria }\end{array}$ & $\begin{array}{l}2.00 \\
2.67 \\
1.99 \\
2.00 \\
2.41 \\
2.00 \\
2.30 \\
2.18 \\
2.00 \\
2.00 \\
2.00 \\
1.87 \\
2.00 \\
2.00 \\
1.96 \\
2.00 \\
2.00 \\
2.00 \\
1.72 \\
2.00\end{array}$ & $\begin{array}{r}510 \pm 90 \\
790 \pm 70 \\
770 \pm 110 \\
1140 \pm 90 \\
1560 \pm 120 \\
1210 \pm 110 \\
1540 \pm 80 \\
1590 \pm 80 \\
1740 \pm 110 \\
1870 \pm 90 \\
3170 \pm 120 \\
1210 \pm 80 \\
2700 \pm 80 \\
720 \pm 110 \\
680 \pm 110 \\
710 \pm 80 \\
1740 \pm 130 \\
1710 \pm 110 \\
1690 \pm 90 \\
2100 \pm 130\end{array}$ \\
\hline $\begin{array}{l}\mathrm{T} 88 / 11 \mathrm{~B} \\
\mathrm{~T} 88 / 11 \mathrm{~B} \\
\mathrm{~T} 88 / 11 \mathrm{~B} \\
\mathrm{~T} 88 / 11 \mathrm{~B} \\
\mathrm{~T} 88 / 11 \mathrm{~B}\end{array}$ & $\begin{array}{l}1018 \\
1019 \\
1020 \\
1021 \\
1022\end{array}$ & $\begin{array}{l}\text { 1. } 0-1 \\
\text { 1. } 0-1 \\
\text { 1. } 0-1 \\
\text { 3. } 0-1 \\
\text { 4. } 0-1\end{array}$ & $\begin{array}{l}\text { Diacria } \\
\text { Diacria } \\
\text { Diacria } \\
\text { Diacria } \\
\text { Diacria }\end{array}$ & $\begin{array}{l}1.80 \\
2.20 \\
2.00 \\
2.70 \\
1.80\end{array}$ & $\begin{array}{r}230 \pm 50 \\
620 \pm 90 \\
620 \pm 50 \\
1570 \pm 60 \\
2130 \pm 90\end{array}$ \\
\hline $\begin{array}{l}\text { T86/10S } \\
\text { T86/10S } \\
\text { T86/10S }\end{array}$ & $\begin{array}{l}662 \\
665 \\
666\end{array}$ & $\begin{array}{l}0-1 \\
0-1 \\
0-1\end{array}$ & $\begin{array}{l}\text { Diacria } \\
\text { Caveolina } \\
\text { Clio }\end{array}$ & $\begin{array}{l}0.99 \\
1.89 \\
1.85\end{array}$ & $\begin{array}{l}-480 \pm 90 \\
-190 \pm 90 \\
1070 \pm 100\end{array}$ \\
\hline $\begin{array}{l}\mathrm{T} 86 / 11 \mathrm{~S} \\
\mathrm{~T} 86 / 11 \mathrm{~S}\end{array}$ & $\begin{array}{l}660 \\
661\end{array}$ & $\begin{array}{l}\text { 1. } 0-1 \\
\text { 3. } 0-1\end{array}$ & $\begin{array}{l}\text { Diacria } \\
\text { Diacria }\end{array}$ & $\begin{array}{l}1.94 \\
1.00\end{array}$ & $\begin{array}{r}32 \pm 60 \\
690 \pm 70\end{array}$ \\
\hline $\begin{array}{l}\text { T86/13B } \\
\text { T86/13B } \\
\text { T86/13B } \\
\text { T86/13B } \\
\text { T86/13B } \\
\text { T86/13B } \\
\text { T86/13B } \\
\text { T86/13B }\end{array}$ & $\begin{array}{l}653 \\
654 \\
735 \\
655 \\
656 \\
657 \\
658 \\
659\end{array}$ & $\begin{array}{l}\text { 1. } 0-1 \\
\text { 2. } 0-1 \\
\text { 3. } 0-1 \\
\text { 4. } 0-1 \\
\text { 5. } 0-1 \\
\text { 1. } 0-1 \\
\text { 2. } 0-1 \\
\text { 3. } 0-1\end{array}$ & $\begin{array}{l}\text { Diacria } \\
\text { Diacria } \\
\text { Diacria } \\
\text { Diacria } \\
\text { Diacria } \\
\text { Cuvierina } \\
\text { Cuvierina } \\
\text { Cuvierina }\end{array}$ & $\begin{array}{l}1.78 \\
1.14 \\
0.30 \\
1.46 \\
1.30 \\
1.30 \\
1.59 \\
1.31\end{array}$ & $\begin{array}{r}10,610 \pm 120 \\
7160 \pm 80 \\
8170 \pm 180 \\
15,600 \pm 200 \\
14,600 \pm 200 \\
10,170 \pm 110 \\
13,400 \pm 300 \\
14,140 \pm 190\end{array}$ \\
\hline
\end{tabular}

*The two DANA samples derive from plankton tows at a depth of $100 \mathrm{~m}$.

**Numbers 1-4 refer to different staining stages of the test of the pteropod species Diacria trispinosa and Cuvierina columnella $(1=$ white; $4=$ dark brown). The four stages are collected both from the $0-2$ as from the $12-14 \mathrm{~cm}$ downcore level. Pteropods from the $12-14 \mathrm{~cm}$ level are all fragmented.

${ }^{\dagger} \Delta^{13} \mathrm{C}$ values measured at the Geology Department, Utrecht.

${ }^{\ddagger}$ Age in years Before Present from ${ }^{14} \mathrm{C}$ activity after normalization to $\delta^{13} \mathrm{C}=-25 \%$. No correction applied for reservoir age. 


\section{RESULTS}

Table 2 lists all AMS ${ }^{14} \mathrm{C}$ measurements performed on our material. In the table, ages are not corrected for reservoir age. The majority of the samples derives from surface sediments, however, preservation horizons downcore were also taken into account (T88/9B). To determine the nature of the surficial pteropod ooze, a foraminiferal sample from T86/5B directly underlying the ooze was measured. Its generally younger age, compared to most ages of the pteropod ooze specimens, indicates that the ooze is a lag deposit. Preservation of the aragonitic shells is strongly enhanced by the $\mathrm{Fe} / \mathrm{Mn}$ coating.

In order to compare these ages to terrestrial chronologies from plant material, a correction for reservoir age has to be made. To achieve this, we measured pteropods collected during the DANA Expeditions in 1931 (thus before atomic pollution) in plankton nets at a depth of $100 \mathrm{~m}$. AMS ${ }^{14} \mathrm{C}$ dates on these specimens yielded ages of 370 and 480 B.P. (average of $425 \mathrm{yrs}$ ), respectively, which is in good agreement with the theoretical reservoir age model of Stuiver, Pearson and Braziunas (1986). However, strictly speaking, the reservoir age is reserved for pre-industrial samples in contrast with pre-bomb samples. ${ }^{14} \mathrm{C}$ dilution by fossil fuels is in the order of $10 \%$ (ca.80 yrs) for North Atlantic surface waters (Druffel \& Suess 1983; Bard et al. 1988). From Figure 3 in Druffel and Suess (1983), it becomes clear that the period after 1930 accounts for the major part of this so-called Suess effect. In the preceding period, dilution is in the order of 2-3\%o (ca. $20 \mathrm{yrs}$ ). As our specimens were collected in 1931, we decided not to correct for the entire Suess effect, but only for samples collected before 1930. Hence, in the text and figures all our data (from uncorrected data in Table 2) are corrected by -400 years for reservoir age. The corrected ages were cumulatively plotted in three different time frames: 16,000-2000 B.P. (Fig. 2), the last 2000 years (Fig. 3), and the period A.D. 1500-1900 (Fig. 4). The implications of the plots are discussed below.

\section{DISCUSSION - PTEROPOD PRESERVATION IN RELATION TO CHANGING CLIMATE}

From our data set, it becomes clear that aragonite preservation is a recurrent feature during the last 16,000 years in the eastern North Atlantic. Figure 2 shows that, on a longer time scale, preservation periods occurred from 15,200-13,000, 10,300-9700, 8000-6000 and 4500-2700 B.P. The first two events correspond to Termination $1 \mathrm{~A}$ and 1B, respectively ( $c f$. Bard et al. 1987); a worldwide preservation peak centered around 14,000 B.P. has also been postulated by Berger (1977). The

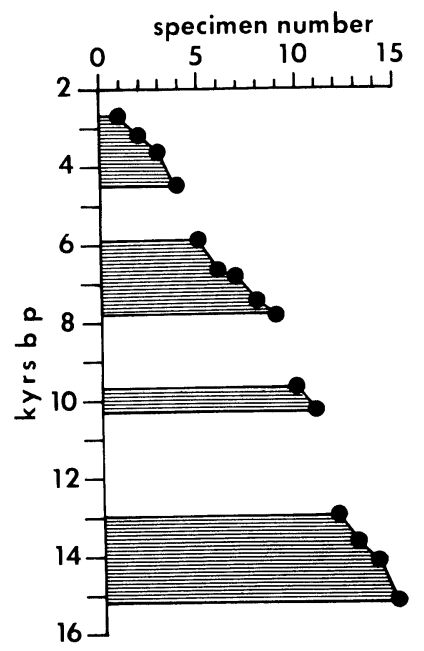

Fig. 2. Cumulative plot of 15 pteropod specimens vs. time (16,000-2000 B.P.). ${ }^{14} \mathrm{C}$ ages corrected for reservoir age by -400 years. Shaded areas indicate periods of aragonite preservation. 


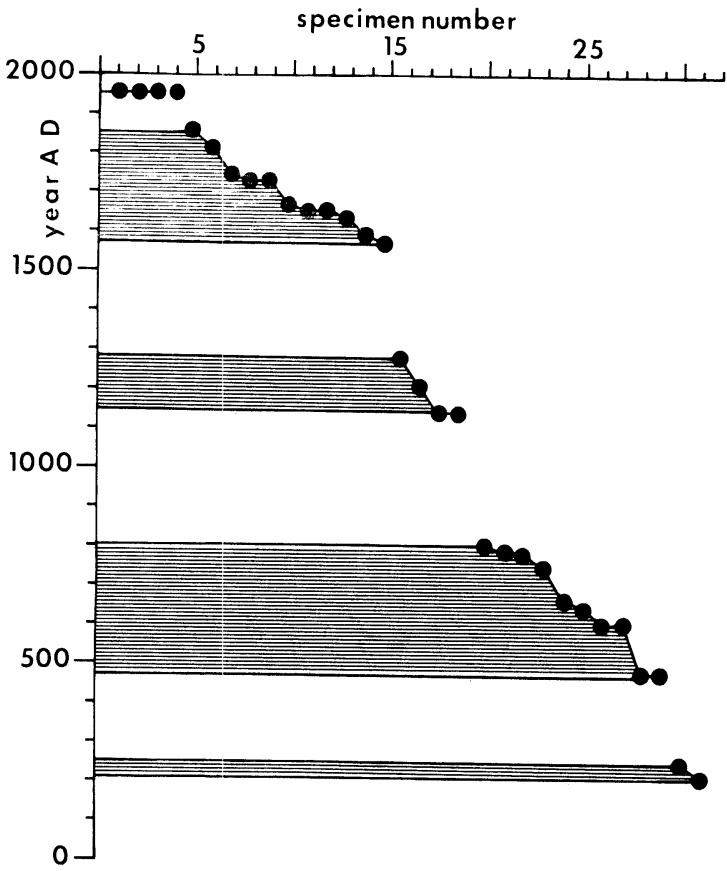

Fig. 3. Cumulative plot of 31 pteropod specimens vs. time (the last 2000 years). ${ }^{14} \mathrm{C}$ ages corrected for reservoir age by -400 years. Shaded areas indicate periods of aragonite preservation.

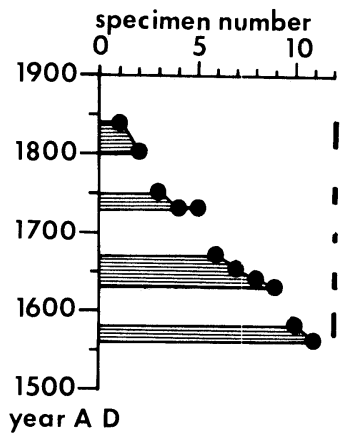

Fig. 4. Cumulative plot of 11 pteropod specimens vs. time (the Little Ice Age). ${ }^{14} \mathrm{C}$ ages corrected for reservoir age by -400 years. Shaded areas indicate periods of aragonite preservation. Vertical bars mark the cold periods as established by Serre-Bachet and Guiot (1987).

third period approximates Termination 1C (Berger 1990); Kassens \& Sarnthein (1989) mention enhanced aragonite preservation around 7000 B.P. in the equatorial Atlantic. The first three preservation spikes are thus strongly correlated to the deglaciation steps following the last glacial maximum. Also, for the period 4500-2700 B.P., a link to climate fluctuations can be made considering major climatic changes at about 4200, 3600 and 2500 B.P. reported by Frenzel (1975).

On a limited time scale (Fig. 3), distinct intervals of aragonite preservation can be observed from A.D. $200-250,480-800,1150-1180,1560-1840$ and Recent. The period, A.D. $1560-1840$, nicely matches the Little Ice Age, which is characterized by various cold spells between 1570 and 1840 (Serre-Bachet \& Guiot 1987). The work of these authors is based on reconstructions of the mean summer temperature by tree-ring densitrometric measurements from the Alps and the Mediterranean region. Plotting our data from this period in an even narrower time frame (Fig. 4), periods of pteropod preservation show a remarkable fit with the cold periods established by Serre-Bachet \& Guiot (1987), i.e., A.D. $1570-1600,1630-1650,1690-1700,1740-1760$ and $1810-1840$, 
although we are aware that, considering the accuracy of the ${ }^{14} \mathrm{C}$ technique and the corrections applied for the reservoir age, a little wishful thinking cannot be excluded.

\section{CONCLUSION}

In summary, conditions leading up to pteropod preservation prevailed during intervals of climatic change, such as the Last Glacial/Holocene transition, the period 4500-2700 B.P. and the Little Ice Age. We conclude that other intervals of aragonite preservation within the last 2000 years also may have been caused by similar short-term periods of climatic change.

\section{ACKNOWLEDGMENTS}

Cruises Tyro 1986/88 were financed by the Dutch Council of Sea Research (SOZ). The manuscript greatly benefitted from critical remarks and helpful suggestions by W. H. Berger and an anonymous reviewer.

\section{REFERENCES}

Bard, E. 1988 Correction of accelerator mass spectrometry ${ }^{14} \mathrm{C}$ ages measured in planktonic foraminifera: paleoceanographic implications. Paleoceanography 3(6): 635-645.

Bard, E., Arnold, M., Maurice, P., Duprat, J., Moyes, J. and Duplessy, J.-C. 1987 Retreat velocity of the North Atlantic polar front during the last deglaciation determined by ${ }^{14} \mathrm{C}$ accelerator mass spectrometry. Nature 328: 791-794.

Berger, W.H. 1977 Deep-sea carbonate and the deglaciation preservation spike in pteropods and foraminifera. Nature 269: 301-304.

1978 Deep-sea carbonate: pteropod distribution and the aragonite compensation depth. Deep Sea Research 25(5): 447-452.

1990 The Younger Dryas cold spell - a search for causes. Global and Planetary Change 89(3): 219237.

Berner, R. A. 1977 Sedimentation and dissolution of pteropods in the ocean. In Andersen, N. R. and Malahoff, A., eds., The Fate of Fossil Fuel $\mathrm{CO}_{2}$ in the Oceans. New York, Plenum Press: 323-343.

Frenzel, B. 1975 The distribution pattern of Holocene climatic change in the Northern Hemisphere. In Lamb, H., convener, Proceedings of the WMO/ IAMAP Symposium on Long-Term Climatic Fluctuations. Geneva, World Meteorological Organization: 105-118.

Ganssen, G. M. and Lutze, G. F. 1982 The aragonite compensation depth at the northeastern Atlantic continental margin. "Meteor" Forschungsergeb C36: $57-59$.
Hut, G., Ostlund, H. G. and van der Borg, K. 1986 Fast and complete $\mathrm{CO} 2$-to-graphite conversion for ${ }^{14} \mathrm{C}$ Accelerator Mass Spectrometry. In Stuiver, M. and Kra, R. S., eds, Proceedings of the 12th International ${ }^{14} \mathrm{C}$ Conference. Radiocarbon 28(2A): 186-190.

Kassens, H. and Sarnthein, M. 1989 A link between paleoceanography, early diagenetic cementation and shear strength maxima in Late Quaternary sediments? Paleoceanography 4(3): 253-269.

Melkert, M. J., Ganssen, G. M., Helder, W. and Troelstra, S. R., in press, Episodic preservation of pteropod oozes in the deep N. E. Atlantic Ocean: Climatic changes and hydrothermal activity. Marine Geology.

Price, B. A., Killingley, J. S. and Berger, W. H. 1985 On the pteropod pavement of the eastern Rio Grande Rise. Marine Geology 64: 217-235.

Serre-Bachet, F. and Guiot J. 1987 Summer temperature changes from tree-rings in the Mediterranean area during the last 800 years. In Berger, W. H. and Labeyrie, L. D., eds, Abrupt Climate Change. Dordrecht, The Netherlands, D. Reidel: 89-97.

Stuiver, M., Pearson, G. W. and Braziunas, T. 1986 Radiocarbon age calibration of marine samples back to $9000 \mathrm{cal}$ yr BP. In Stuiver, M. and Kra, R. S., eds, Proceedings of the 12 th International ${ }^{14} \mathrm{C}$ Conference. Radiocarbon 28(2B): 980-1021.

Troelstra, S. R., Ganssen, G. M., Sennema, E. J., Klaver, G. Th., Alderliesten, C., van der Borg, K. and de Jong, A. M. F. 1987 Late Quaternary stratigraphy and sedimentology of the central North Atlantic: A progress report. Nuclear Instruments and Methods B29: 317-321. 